\title{
KAKAOKTT: SPSS MAKRO ZA AJTEM ANALIZU - KLASIČNI MODEL ${ }^{1}$
}

\section{Stanislav Fajgelj²,}

Fakultet za pravne i poslovne studije, Novi Sad

\section{Bojan Janičić}

Odsek za psihologiju, Filozofski fakultet, Novi Sad

U radu je prikazan KAKAOKTT, jedan od programa za ajtem analizu testa iz skupa KAKAO. Skup KAKAO je namenjen ajtem analizi mernih instrumenata iz oblasti nauka o ponašanju. Programi su izrađeni u Matrix jeziku, kao makroi u okviru statističkog paketa SPSS. To su makro programi otvorenog koda (open source), besplatni su, za njihovo odvijanje potreban je statistički paket SPSS $i$ vrlo su jednostavni za upotrebu. Makro KakaoKTT je namenjen ajtem analizi zasnovanoj na klasičnoj testnoj teoriji. Sadrži probrani skup mernih karakteristika ajtema i testa, kao i kratak opis svakog prikazanog koeficijenta. Osim klasičnih pokazatelja obuhvaćeni su i pokazatelji mernih svojstava bazirani na Gutmanovom mernom modelu. KakaoKTT prihvata dihotomne i polihotomne ajteme koji su skorovani u istom smeru.

Ključne reči: ajtem analiza, klasična testna teorija, Guttmanov model merenja

\footnotetext{
${ }^{1}$ Rad u okviru projekata broj 149008b "Psihološke karakteristike društva u tranziciji” kojeg finansira Ministarstvo nauke i zaštite životne sredine Republike Srbije i broj 149027 „Integralni razvoj, fizička aktivnost i aberantno ponašanje predškolske dece“, kojeg sufinansira Ministarstvo za nauku i tehnološki razvoj.

${ }^{2}$ E-mail: stanef@beocity.net.
} 


\section{Uvod}

Skup programa pod zajedničkim nazivom Kakao, namenjen je ajtem analizi mernih instrumenata iz oblasti nauka o ponašanju. U takve instrumente spadaju, pre svega, grupni psihološki štampani testovi koji su objektivno ocenjivani, tj. oni koji se u žargonu nazivaju "psihometrijskim". To mogu biti kognitivni testovi, onakvi kakvi se koriste u psihološkom i pedagoškom testiranju, testovi ličnosti (konativni) i skale stavova. Međutim, mogu biti analizirani i rezultati svakog drugog merenja, ukoliko zadovoljavaju opšte pretpostavke modela merenja na kojima se programi zasnivaju.

Ovaj skup programa izrađen je za potrebe istraživanja u okviru projekata "Psihološke karakteristike društva u tranziciji" i „Integralni razvoj, fizička aktivnost i aberantno ponašanje predškolske dece", ali je namenjen psiholozima i svima onima koji konstruišu ili evaluiraju takve merne instrumente. Takođe, programi su namenjeni studentima, kao pomoćno sredstvo u univerzitetskoj nastavi. U oblasti klasične testne teorije Kakao se okvirno može porediti sa sličnim dostupnim procedurama iz poznatih statističkih paketa (SPSS i Statistica $^{3}$. Ono po čemu se KakaoKTT razlikuje je niz psihometrijskih pokazatelja proisteklih iz višedecenijske radionice velikog broja autora pod rukovodstvom prof. Konstantina Momirovića. U Srbiji odavno cirkuliše više verzija jednog programa pod zbirnim nazivom "rtt9" (Knežević i Momirović, 1996), pa je s obzirom na njegovu popularnost bilo izvesno da su takve alatke potrebne i korisne. Kakao sledi $r t t 9$ u oblasti klasične testne teorije i u pogledu usvojenog programskog rešenja (makro program pisan u Matrixu za SPSS). Rtt9 sadrži znatno veći broj indikatora mernih svojstava, od kojih većina, po našem mišljenju, nije našla praktičnu primenu. Naša namera je bila: a) da zadržimo domaći pristup psihometriji, postavljen radom Momirovića i saradnika, b) da zadržimo izvestan broj pokazatelja koji su kroz dosadašnju upotrebu pokazali utemeljenost i c) da program dopunimo nekim uobičajenim pokazateljima i informacijama kako bi mogao postati standardna alatka domaćih psihologa za evaluaciju testova.

\footnotetext{
${ }^{3}$ Svi Kakao makroi mogu se dobiti direktno od autora putem e-maila janicic@uns.ns.ac.yu, ili na: http://www.cpijm.org.yu/sfstuff/index.htm.
} 


\section{Ajtem analiza po klasičnoj teoriji testa - program KakaoKTT}

U klasičnoj teoriji testa (KTT) se govori o mernim svojstvima ajtema i testova. Merna svojstva ajtema se razlikuju od mernih svojstava testa, a osim toga, pokazatelji mernih svojstava se iskazuju na različitim skalama. Povrh svega, postoji veliki broj različitih pokazatelja za isto merno svojstvo. To je idealna situacija za pisca softvera jer ima široku slobodu izbora, ali nije pogodno za psihologe koji bi evaluaciju testova želeli da obavljaju u istom referentnom okviru, na osnovu uporedivih indikatora.

Veliki broj pokazatelja mernih karakteristika može se izračunati u okviru ajtem analize, a za ostale pokazatelje su potrebne dodatne, eksterne varijable. Ajtem analiza testa po KTT počiva na dva osnovna izvora podataka: prva dva momenta distribucije ajtemskih odgovora i matrici ajtemskih korelacija (kovarijansi). Pearsonove korelacije su temelj klasične ajtem analize još od Spearmana.

Računajući na ova dva osnovna izvora podataka za ajtem analizu, napravili smo takav izbor koeficijenata koji informisanom korisniku pruža dovoljnu podršku za konstrukciju ili evaluaciju testa. Kao prvo, obuhvatili smo osnovna ajtemska merna svojstva - težinu i diskriminativnost. Težina i diskriminativnost su temelj odlučivanja o podobnosti svakog ajtema, a pri konstrukciji i rekonstrukciji testa od njih, na prvom mestu, zavisi da li će ajtem biti zadržan u testu ili neće.

Zatim, izračunava se i niz pokazatelja koji se odnose na interrelacije ajtema, relacije svakog ajtema sa ostalim, relacije sa predmetom merenja testa (osobinom), kao i svojstvene vrednosti matrice interkorelacija ajtema. Ova grupa pokazatelja namenjena je, pre svega, da korisniku pomogne u proceni da li je test jedodimenzionalan, odnosno homogen i koji ajtemi tome doprinose više, a koji manje. Nažalost, kvantifikacija jednodimenzionalnosti je i dalje sasvim otvoren psihometrijski problem i za nju ne raspolažemo nekom konačnom tehnikom. Danas je dosta popularan način da se primeni konfirmativna faktorska analiza, tako da se pomoću nje testira merni model sa jednim faktorom - latentnom varijablom. To rešenje je komplikovano i u praksi (i u suštini) ne dokazuje jednodimenzionalnost. Jednostavnije, a takođe popularno rešenje, je tzv. paralelna analiza (npr. Thompson, 2004), koja postoji u više varijanti a za koju, ono što je ovde značajno, postoji i softverska podrška u obliku SPSS makroa (O'Connors, 2000). Klasična testna teorija nije nastala kao striktan matematički model, kakav je, na primer, teorija ajtemskog odgovora. Zato se u njoj prilično dosledno izvrdava provera fitovanja modela, tj. da li podaci ispunjavaju pretpostavke postavljene modelom. Međutim, ona jeste model i 
ako, na primer, ajtemi ne ispunjavaju kriterijume paralelnih indikatora ili pripadnosti istom domenu, onda su i pokazatelji mernih svojstava koji su izvedeni iz tog modela neprimenjivi. Apsolutno minimalan kriterijum za primenu bilo kog od indikatora i koeficijenata obuhvaćenih KakaoKTT-om je kongeneričnost. Zbog toga $u$ listingu dajemo priličan broj pokazatelja na osnovu kojih se može oceniti kongeneričnost.

Nakon toga slede dijagnostički podaci o testu u celini: momenti distribucije ukupnog skora i serija pokazatelja koji se odnose na pouzdanost testa i standardnu grešku merenja.

Glavnina pokazatelja je izvedena na bazi izvornog klasičnog modela: $Y=T+$ $E$. Osim tih pokazatelja, iz programa $r t t 9$ preuzeli smo i nekoliko pokazatelja koji se baziraju na Guttmanovom modelu merenja, u koji ubrajamo i tzv. Harrisovu transformaciju. Iz pojmovnog prostora Guttmanove imaž teorije potiču faktorska opterećenja ajtema na prvoj glavnoj komponenti iz Harrisove reskalirane matrice kovarijansi, pokazatelji reprezentativnosti ajtema i testa, kao i nekoliko koeficijenata pouzdanosti koje je predložio Momirović (Knežević i Momirović, 1996, Momirović, Wolf i Popović, 1999).

Razlozi zbog kojih smo uvrstili ove pokazatelje su sledeći. Guttmanov model nosi specifičnosti zbog kojih njegovi pokazatelji mogu biti dopunska informacija o testu. Da podsetimo, Guttmanov model se od ostalih klasičnih modela razlikuje po tome što su mu greške merenja izračunljive (iako korelirane). Imaž ajtema je dobro i zdravo zasnovana procena prave varijanse ajtema, a antiimaž pogrešne (doduše, za parcijalni imaž i antiimaž to važi $u$ manjoj meri, ali suština svakog modela jeste hipotetičnost). Reprezentativnost je danas manje više opšte prihvaćena merna karakteristika testa, a definisana je samo u Guttmanovom modelu. Na osnovu Harrisovih radova u oblasti faktorske analize došlo se do zaključka da ajtemi koji su transformisani u Harrisovu metriku (Momirović je naziva univerzalnom) imaju neka pogodna svojstva, pre svega to da su maksimalno pouzdani. Pojednostavljeno rečeno, svi "Guttmanovi" pokazatelji u KakaoKTT mogu se tumačiti kao da potiču od pročišćenih ajtema, kojima je odstranjena unikna varijansa (specifitet + greška) i ostala samo prava varijansa. To sledi iz Guttmanovog modela, ali ne znači da podaci uvek fituju takav model (Momirović i sar., 1999, McDonald, 1999, Mulaik, 1972, Gorsuch, 1974, Fajgelj, 2005, Harris, 1962).

S obzirom da su programi pisani u Matrix jeziku, koristićemo matričnu notaciju za osnovne definicije. Ako matricu podataka, koja je reda $n \times m$, označimo sa $\mathbf{X}$, onda aritmetičke sredine možemo dobiti sa: 


$$
\mathrm{M}=\mathrm{X}^{\prime} \mathrm{X} n^{-1},
$$

a varijanse kao $\mathrm{D}^{2}=\operatorname{diag}\left(\mathbf{X}_{\mathrm{c}}{ }^{\prime} \mathbf{X}_{\mathrm{c}}\right)$, gde je matrica devijacionih skorova:

$$
\mathrm{X}_{\mathrm{c}}=\mathrm{HX} n^{-1 / 2}
$$

a matrica $\mathrm{H}$ je centroidni projektor. Matrica (tačnije vektor) $\mathbf{M}$ predstavlja težine ajtema, a standardne devijacije ajtema se nalaze u D.

Matricu interkorelacija ajtema možemo izračunati kao:

$$
\mathrm{R}=\mathrm{Z}^{\prime} \mathrm{Zn}^{-1}=\mathrm{D}^{-1} \mathrm{X}^{\prime} \mathrm{HXD}^{-1} n^{-1} .
$$

Čuveni Guttmanov rezultat, matrica pogrešnih varijansi, odnosno matrica parcijalnih antiimaža, izračunava se kao:

$$
\mathbf{V}^{2}=\operatorname{diag}\left(\mathbf{R}^{-1}\right)^{-1}
$$

Kovarijanse imaža se sada mogu izračunati kao:

$$
\mathbf{G}=\mathbf{R}+\mathbf{V}^{2} \mathbf{R}^{-1} \mathbf{V}^{2}-2 \mathbf{V}^{2}
$$

a kovarijanse antiimaža kao:

$$
\mathrm{Q}=\mathrm{V}^{2} \mathbf{R}^{-1} \mathbf{V}^{2}
$$

Iz matrica R, G i Q izračunavaju se prosečne korelacije (kovarijanse) za ajteme i za matricu u celini. Prosečne korelacije računaju se kao "root-mean-square" (RMS), kao i preko Fisherovih $z$ transformisanih koeficijenata korelacije. U dijagonali matrice $\mathbf{G}$ su poznati koeficijenti determinacije koji se prikazuju pod nazivom SMC (squared multiple correlation).

Koeficijenti diskriminativnosti se računaju kao korigovane ajtem-total korelacije, po formuli:

$$
r_{j(Y-j)}=\frac{r_{j Y} \sigma_{Y}-\sigma_{j}}{\sqrt{\sigma_{j}^{2}+\sigma_{Y}^{2}-2 \sigma_{j} \sigma_{Y} r_{j Y}}}
$$

a prikazuju se i proste linearne korelacije ajtema i testa $-r_{j Y}$.

U programu se rešavaju svojstvene jednačine $(R-\Lambda) L=0$ i $\left(R_{H}-\Lambda_{H}\right) L_{H}=0$ matrica $R$ i $R_{H}$, pri čemu je $R_{H}=V^{-1} \mathbf{R V}^{-1}$ i predstavlja matricu kovarijansi ajtema reskaliranih u Harrisovu metriku. Matrice $\Lambda, \mathrm{L}, \Lambda_{\mathrm{H}}$ i $\mathrm{L}_{\mathrm{H}}$ su matrice svojstvenih vrednosti i svojstvenih vektora, respektivno. Program izračunava faktorska opterećenja na prvim glavnim komponentama matrica $\mathbf{R}$ i $\mathbf{R}_{\mathrm{H}}$ kao $\mathbf{l} \lambda$ i $l_{H} \lambda_{H}$ i prikazuje ih (parovi 1 i $\lambda$ označavaju prve svojstvene vektore i prve svojstvene vrednosti). 
$\mathrm{Na}$ kraju, izračunava se standardni Cronbachov $\alpha$-koeficijent pouzdanosti interne konzistencije, po standardnoj formuli. Njega sledi nepristrasna procena pouzdanosti u populaciji, procenjena na osnovu $\alpha$-koeficijenta: $\alpha^{\prime}=[2$ $+\alpha(n-3)] /(n-1)$, gde je $n$ veličina uzorka. Zatim se izračunava generalizovani Spearman-Brownov (SB) koeficijent: $r_{t t}=m r^{*} /\left[1+r^{*}(m-1)\right]$, pri čemu se prosečna korelacija $r^{*}$ izračunava preko Fisherovog $z$. SpearmanBrownov $r_{t t}$ se može koristiti u formulama za "proricanje" dužine testa za datu pouzdanost i obrnuto. Na koji način? Ako imamo neki test dužine $m_{1}$ i pouzdanosti $r_{11}$ i produžili smo ga tako što smo mu dodali paralelne ajteme iz istog domena. Formula za izračunavanje pouzdanosti novog testa, dužine $m_{2}$, biće sada:

$$
r_{22}=\frac{k r_{11}}{1+(k-1) r_{11}},
$$

pri čemu je $k=m_{2} / m_{1}$. Prostim izvođenjem može se dobiti i potrebna dužina testa, ako želimo da on ima neku zadatu pouzdanost. Koeficijent kojim treba pomnožiti staru dužinu testa se dobija iz:

$$
k=\frac{r_{22}\left(1-r_{11}\right)}{r_{11}\left(1-r_{22}\right)} .
$$

Ove formule treba shvatiti samo okvirno, zato što podaci retko fituju strog model paralelnih indikatora na kome počiva SB formula. Međutim, kada se izračunaju, pružaju informativan uvid u značaj koji dužina testa ima za pouzdanost u klasičnoj testnoj teoriji. Originalna SB pouzdanost, poznata kao "split-half", po definiciji bi trebala biti niža od $\alpha$-koeficijenta ukoliko skup ajtema ne čini paralelni skup. Međutim, u generalizovanom obrascu, koji se računa na osnovu prosečne interajtemske korelacije, to nije uvek tako.

Slede dva Guttmanova koeficijenta:

$$
\lambda_{1}=1-\sum \sigma_{j}^{2} / \sigma^{2}
$$

i

$$
\lambda_{6}=1-\left(\mathbf{e}^{\prime} \mathbf{V}^{2} \mathbf{e} / \sigma^{2}\right) .
$$


Za prvi je Guttman smatrao da predstavlja apsolutnu donju granicu pouzdanosti datih podataka. Koeficijent $\lambda_{6}$ se zasniva na udelu antiimaža ajtema u varijansi ukupnog skora, čime sledi logiku Guttmanovog modela da antiimaž treba tretirati kao varijansu greške. Specifičnost $\lambda_{6}$ je to što može biti negativan, ali smo u KakaoKTT usvojili uobičajenu konvenciju da ga u tom slučaju izjednačimo sa nulom.

Sledi koeficijent:

$$
\beta_{6}=1-\left(\mathbf{l}^{\prime} \mathbf{V}^{2} \mathbf{I}\right) / \lambda,
$$

koji predstavlja Momirovićevu očiglednu reformulaciju $\lambda_{6}$, samo što se drugačije definiše prava i pogrešna varijansa. Uobičajeno je da je $\beta_{6}$ veća od $\alpha$, a razlika je sve veća što skup ajtema više odstupa od $\tau$-ekvivalentnog modela. Konačno, koeficijent:

$$
\rho=1-\lambda_{H}{ }^{-1}
$$

je po Kneževiću i Momiroviću analogan $\lambda_{6}$, pa i $\beta_{6}$, ali u prostoru ajtema koji su reskalirani u Harrisovu metriku. S obzirom da su Harrisove varijable koncipirane kao varijable sa maksimalnom pouzdanošću, $\rho$ je obično najviši koeficijent pouzdanosti u KakaoKTT (Momirović, Wolf i Popović, 1999).

Nakon toga sledi indeks pouzdanosti $r_{j T}=r_{t t}^{0,5}$, koji se tumači kao korelacija dobijenog i pravog skora. Iza toga se prikazuju dve standardne greške. Naime, ako se malo bolje pročita literatura, vidi se da u regresionom prikazu pravi i opaženi skor mogu naizmenično biti zavisna i nezavisna varijabla. S obzirom da regresione jednačine nisu jednake kada zavisna i nezavisna varijable promene mesta, nisu jednake ni standardne greške ocene, koje ovde imaju status standardne greške merenja. Mi izračunavamo obe standardne greške kao:

$$
\begin{gathered}
S G M=\sigma\left(1-r_{t t}\right)^{0,5} \\
S T M=\sigma\left[r_{t t}\left(1-r_{t t}\right)\right]^{0,5} .
\end{gathered}
$$

Ako se intervali poverenja formiraju iz $S G M$, oni se moraju formirati oko pravih skorova, a ako se formiraju iz $S T M$, onda se moraju formirati oko dobijenih skorova (Fajgelj, 2005, Nunnally i Bernstein, 1994). 


\section{Opšti opis programa}

Program je napisan u matričnom metajeziku Matrix u okviru statističkog paketa SPSS, a realizovan je kao makro u okviru istog paketa (SPSS, 2005). Makro izvedba omogućuje da se programi jednostavno pozivaju (kao nove komande SPSS-a) i da im se jednostavno prenose parametri. Korisnik u redovnoj upotrebi ne mora da manipuliše izvornim kodom programa, niti da ima bilo kakvog dodira sa njime.

Nastojali smo da oprema svih Kakao programa bude što ujednačenija. To je dobro i za korisnika i za programere. Korisnik se susreće sa usaglašenom terminologijom $\mathrm{i}$ ispisom rezultata analize (output), a programerima je olakšano održavanje i razvoj programa. Za sada, Kakao serija, pored klasične testne teorije, sadrži i programe KakaoBejz i KakaoMiks, u okviru teorije ajtemskog odgovora, za dihotomne i polihotomne ajteme i za 1PL i 2PL modele.

\section{Program KakaoKTT}

KakaoKTT se aktivira na sledeći način:

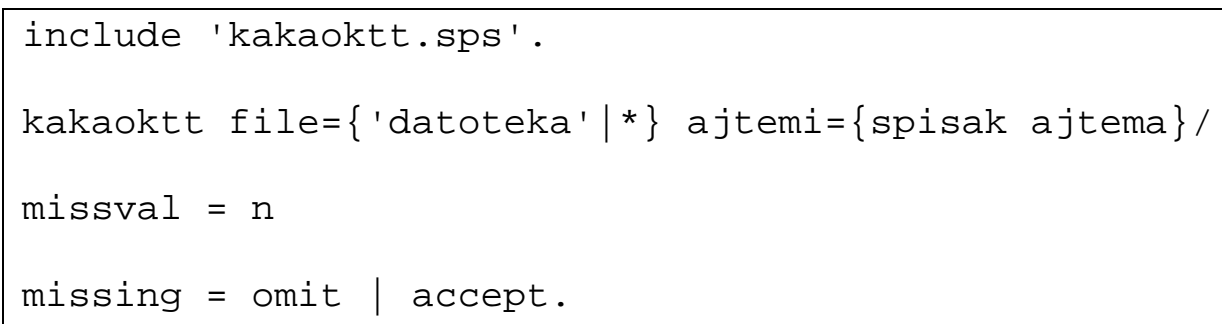

Obavezna je samo opcija ajtemi. U njoj je potrebno navesti nazive ajtema, razdvojene blankom ili zarezom. Moguće je spisak ajtema dati i u formi ajt1 TO ajtn. Na taj način će u analizu biti uvrštene sve stavke koje se u datoteci sa podacima nalaze između ajt1 i ajtn (uključujući i njih). Ukoliko se izostavi opcija file, ili se umesto naziva datoteke upiše *, analiza će biti izvršena na tekućoj datoteci (radnoj).

Sa missval se zadaje vrednost kojom će biti zamenjene sve ispuštene vrednosti u podacima (korisničke i sistemske). Opcija je aktivna samo ako se zada missing="accept", inače nema funkciju. Automatska vrednost je nula. Opcijom missing se određuje tretman ispuštenih vrednosti. Ako je „omit“ (što je automatska vrednost) odbacuju se svi slučajevi koji imaju barem jednu 
ispuštenu vrednost („listwise“ strategija po terminologiji SPSS-a). Ako je „accept“, onda će sve ispuštene vrednosti biti zamenjene vrednošću missval. Ako ove varijante tretmana ispuštenih vrednosti nisu zadovoljavajuće, korisnik mora prethodno u podacima sprovesti prešifriranje ili deklarisanje ispuštenih vrednosti.

U komandi include potrebno je navesti punu putanju do datoteke koja sadrži definiciju makroa (npr. ' C: \KAKAO\kakaoktt. sps ' ). Isto važi i prilikom navođenja naziva datoteke sa podacima.

\section{Ispis rezultata programa}

U primeru su korišćeni neki ajtemi iz testa aberantnog ponašanja dece. Ajtemi su politomni, u Likertovom formatu 1-5.

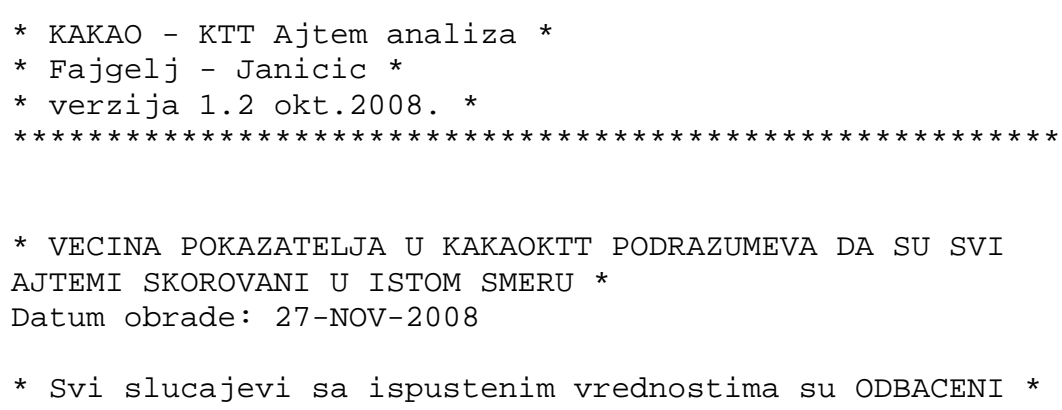




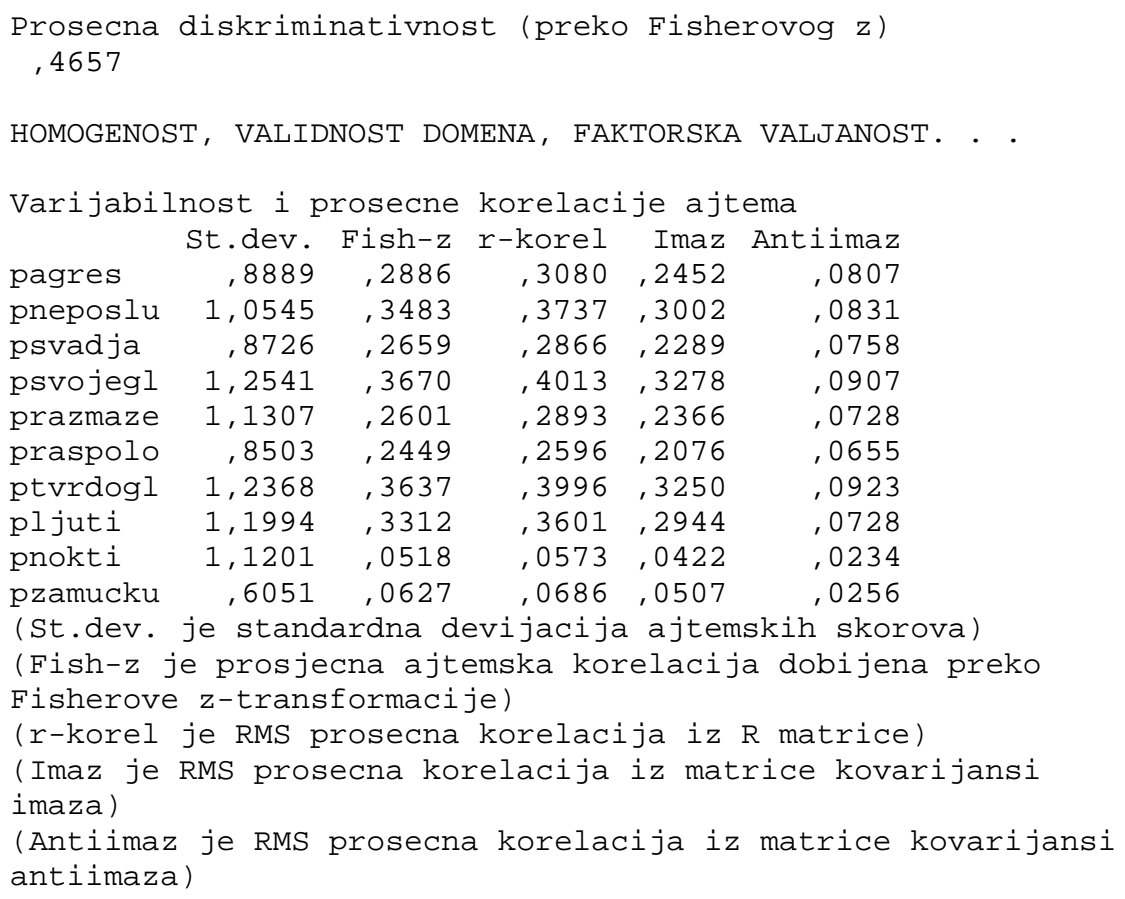

Pošto se težina ajtema izračunava kao aritmetička sredina, nedostaje još standardna devijacija, zbog čega je ona uključena u prethodnu tabelu. Prirodno je da vrlo laki i vrlo teški ajtemi imaju nižu standardnu devijaciju. Ako $\sigma$ nekog ajtema jako odudara od ostalih, posebno ako je jako niska (npr. ispod $10 \%$ od aritmetičke sredine), onda taj ajtem sigurno neće imati dobra merna svojstva. Pri tome treba imati u vidu da su sva merna svojstva po KTT vezana za konkretan uzorak ispitanika. Isti ajtem i isti test na drugom uzorku (i drugim uslovima testiranja) mogu imati drastično različita merna svojstva. Zavisnost mernih svojstava od uzorka se smatra teškim i teško otklonjivim nedostatkom KTT i taj nedostatak je trebala da otkloni teorija ajtemskog odgovora, sa dosada nepoznatom uspešnošću.

Prosečne korelacije ukazuju na homogenost testa. Ako su one niske, onda najverovatnije svi ajtemi nemaju zajednički predmet merenja (konstrukt) ili su greške merenja visoke. RMS korelacija je obično veća od one koja se dobija iz Fisherove $z$-transformacije i ta razlika je to veća što je raspon korelacija veći (u narednoj tabeli se mogu videti minimalna i maksimalna korelacija). Postoji uverenje da je prosečna korelacija dobijena preko Fisherove $z$-transformacije bolja. 
Što se tiče prosečne kovarijanse u matrici kovarijansi imaža i antiimaža, treba se podsetiti donekle pojednostavljenog opisa da su imaži procena prave, a antiimaži procena pogrešne varijanse. $\mathrm{S}$ obzirom da u klasičnom modelu greške ne koreliraju, kovarijanse antiimaža bi trebale biti bliske nuli i svakako znatno niže od kovarijansi imaža. Visoke kovarijanse antiimaža obično se sreću kod ajtema koji čine testlete (pakete), odnosno dele između sebe neki zajednički kontekst, koji ne dele ostali ajtemi u testu. Ako ajtemi nisu namerno tako konstruisani da čine testlete, onda se visoka kovarijansa antiimaža treba smatrati neprihvatljivom.

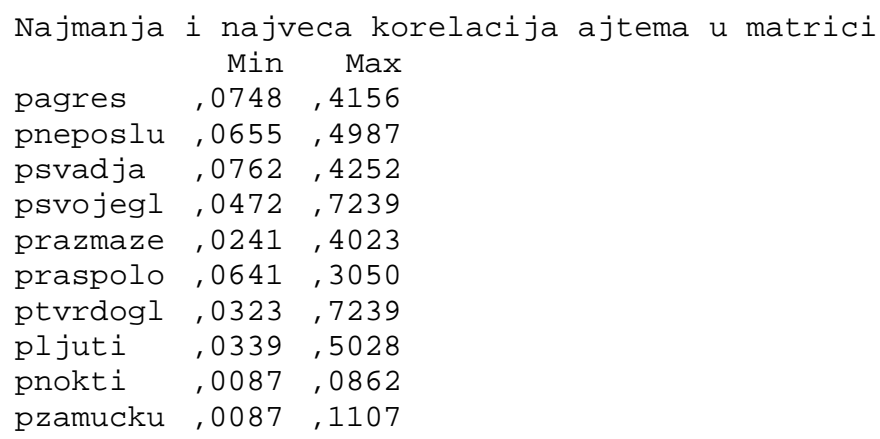

Prvenstvena namena prethodne tabele je da se ukaže na pogrešno skorovane ajteme, ili na ajteme koji imaju visoke negativne korelacije.

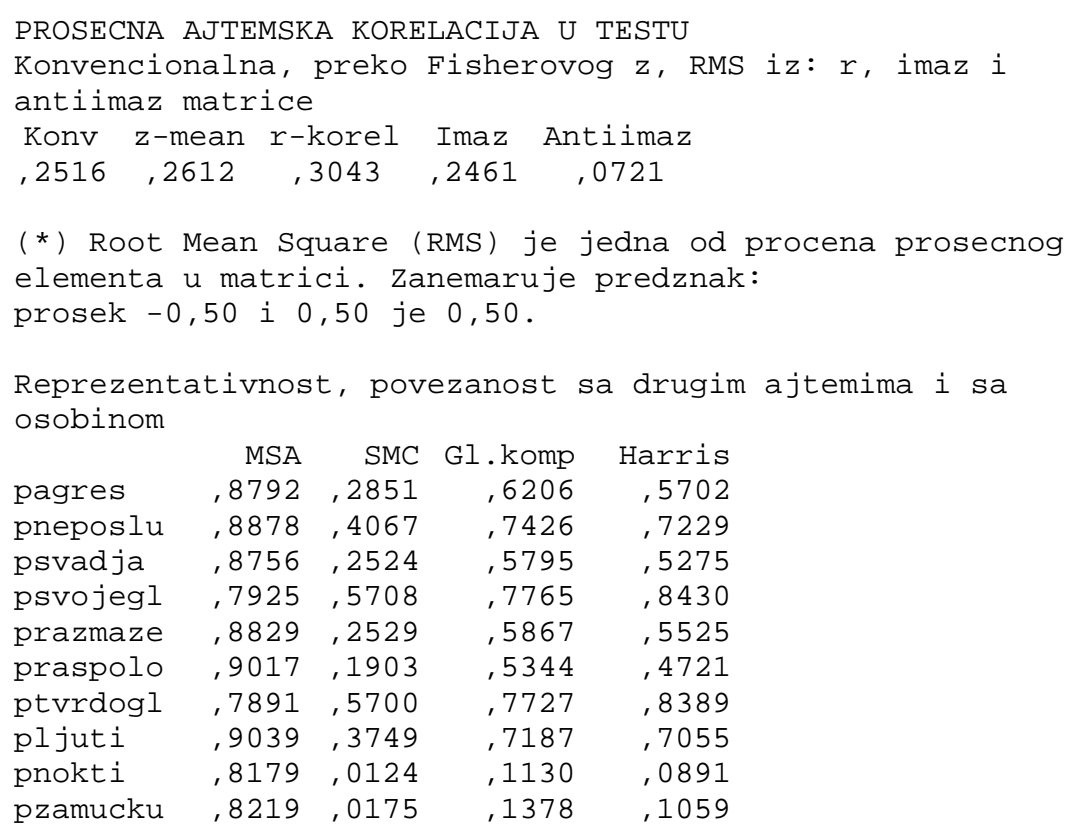


(MSA koeficijenti reprezentativnosti)

(SMC su koeficijenti determinacije)

(Gl.komp je opterecenje na prvoj glavnoj komponenti)

(Harris je opterecenje na prvoj glavnoj komponenti u univerzalnoj metrici)

Koeficijent reprezentativnosti, odnosno "Measure of Sampling Adequacy" je pokušaj Henryja Kaisera da kvantifikuje podobnost skupa ajtema za faktorsku analizu i baziran je na Guttmanovom modelu. Za ajteme koji imaju nisku reprezentativnost možemo sumnjati da ne pripadaju domenu osobine koju mere ostali ajtemi (Kaiserova šaljiva skala graničnih vrednosti za MSA se štampa na kraju listinga, u prevodu Milade Grginčević). Kaiser kaže da je MSA funkcija četiri glavna uticaja. Ukoliko je drugo konstantno, MSA će biti sve veći što je: a) veći broj varijabli - $m$, b) skup ajtema više jednodimenzionalan-kongenerički ( $u$ terminima faktorske analize to znači da test ima što manje valjanih faktora), c) veći uzorak ispitanika $-n$, i d) prosečna korelacija u matrici $R$ veća. Koeficijenti determinacije nisu ništa drugo do imaži svakog ajtema i predstavljaju proporciju varijanse koju taj ajtem deli sa ostalima. Kod tumačenja faktorskih opterećenja iz dve zadnje kolone treba imati u vidu da su u prvoj koloni prve glavne komponete izračunate na "punim“ varijablama (sa punom varijansom), a u drugoj prve glavne komponente na Harrisovim varijablama, čija je varijansa svedena na zajedničku varijansu, korigovanu prisustvom antiimaža. Drugim rečima, Harrisova faktorska opterećenja su izvestan indikator koliko bi ajtem korelirao sa jednom glavnom osobinom/konstruktom, onom koja se faktorski može izdvojiti kod svih ajtema. Ako svi ajtemi ne dele takvu osobinu, drugim rečima ako test nije jednodimenzionalan, onda će opterećenja na Harrisovoj glavnoj komponenti biti niska, upadljivo niža od onih na sirovoj prvoj glavnoj komponenti.

Sva ova četiri koeficijenta (iz četiri kolone) ciljaju u istu metu: da li je test homogen, tj. da li svi ajtemi imaju zajedničko jezgro i ako nemaju, koji su. Ako je rang ajtema jednak u sve četiri kolone, onda je tumačenje jednostavno. Međutim, ako je ajtem u jednoj koloni „dobar“, a u drugoj „loš“, nema jednostavnog uputstva za odlučivanje. Mogući razlozi za to su da je ajtem pretežak ili prelagan, da ima "specijalne“ veze sa nekim ajtemima (npr. supresorske), da skup ajtema ne odgovara modelu uzorkovanja iz domena ili modelu paralelnih indikatora, odnosno da generalno nije jednodimenzionalan.

Svojstvene vrednosti matrice interkorelacija ajtema,
$\begin{array}{lrcl}\text { kumulativ } i \% \\ \text { Lambda } & \% & \text { Kumul. } & \text { Kum. } \% \\ 4,3569 & 43,5690 & 4,3569 & 43,5690 \\ 1,0427 & 10,4265 & 5,3996 & 53,9956 \\ \text {,9072 } & 9,0724 & 6,3068 & 63,0679\end{array}$




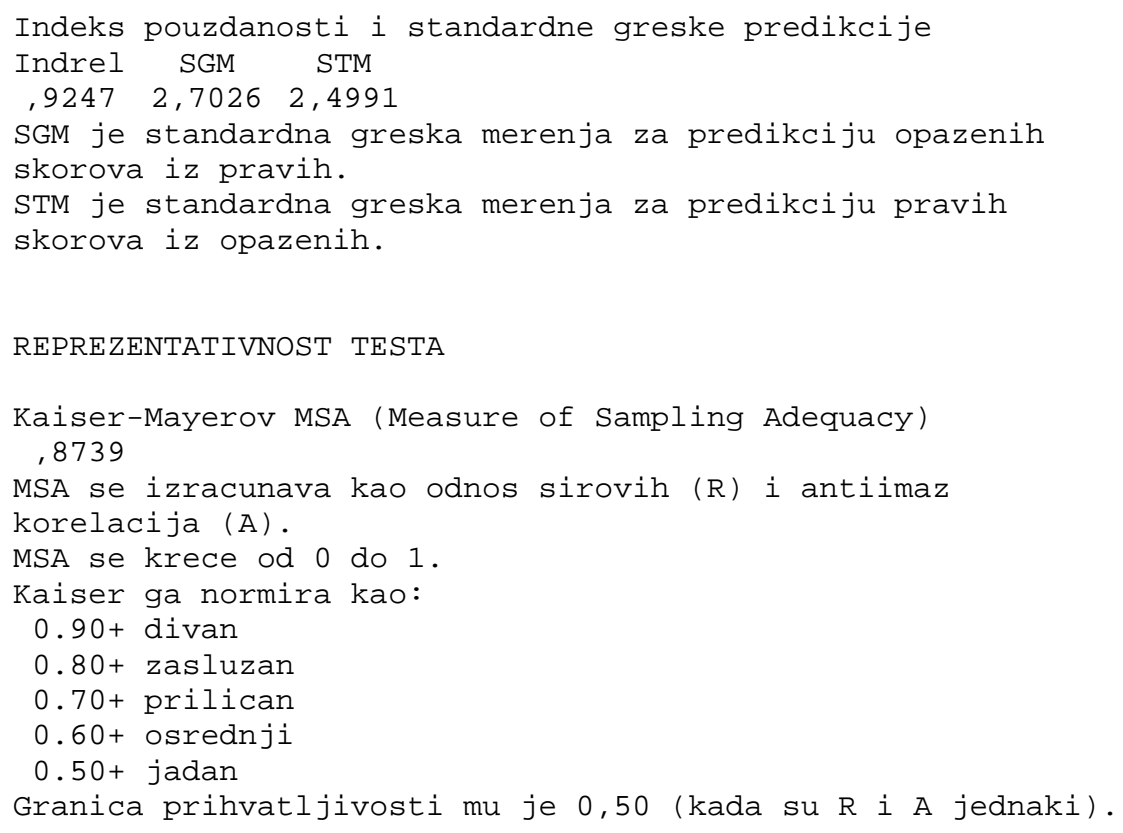

Prethodni koeficijenti se odnose na test u celini. Dominantan podatak je svakako $\alpha$, koeficijent pouzdanosti interne konzistencije. Kada je manji od 0,7, smatra se neprihvatljivim, ako je iznad 0,83 smatra se optimalnim, a ako je iznad 0,9 onda je vrlo visok i zbog paradoksa atenuacije može biti krivac sniženoj validnosti testa. Uvek treba imati na umu da pouzdanost interne konzistencije u KTT zavisi od dužine testa $-\alpha$ favorizuje duge testove.

Kada je reč o validnosti, KakaoKTT ne može poslužiti za ocenu kriterijumske validnosti testa - za to su potrebne eksterne varijable. Međutim, okvirna procena konstruktivne validnosti je moguća i za nju će poslužiti svi indikatori koji su namenjeni proceni jednodimenzionalnosti, koji u određenoj meri mogu poslužiti i za procenu sadržinske validnosti. Naime, ako test jeste homogen, on je verovatno konstruktivno i sadržinski valjan, ali ako nije homogen, i dalje može biti sadržinski valjan. Takođe, nisko pouzdan test verovatno neće biti valjan, posebno ne kriterijumski valjan (test koji ima visoke greške ne može korelirati ni sa jednom drugom varijablom). Koeficijenti težine ajtema i diskriminativnosti takođe mogu pomoći u sadržinskoj validaciji.

Krajnje dobra praksa je da se izračunaju intervali poverenja, recimo kao: $Y \pm 2 S T M$. U tom intervalu oko nekog dobijenog skora $Y$ možemo očekivati da će se nalaziti pravi skor, sa verovatnoćom od oko 0,954. 
Vreme izvršavanja programa

Vremena izvršavanja makroa merena su na računaru sledeće konfiguracije: AMD Athlon ${ }^{\text {Th }}$ XP 2000+, 1,67 GHz, sa 768 RAM.

KakaoKTT se izvršava za manje od sekunde bez obzira na broj stavki i veličinu uzorka.

\section{Reference}

Fajgelj, S. (2005). Psihometrija: Metod i teorija psihološkog merenja (2. izdanje). Beograd: Centar za primenjenu psihologiju.

Gorsuch, R. L. (1974). Factor analysis. London: W.B. Saunders Company.

Harris, C. W. (1962). Some Rao-Guttman relationships, Psychometrika, 27, 247-263.

Knežević, G., Momirović, K. (1996). RTT9G, program za analizu metrijskih karakteristika kompozitnih mernih instrumenata. U P. Kostić (ur.), Problemi merenja u psihologiji, 2, 37-56. Beograd: Institut za kriminološka i sociološka istraživanja.

McDonald, R.P. (1999). Test theory: A unified treatment. Mahwah, New Jersey: Lawrence Erlbaum Assoc..

Momirović, K., Wolf, B. Popović, B. (1999). Uvod u teoriju merenja, I. Metrijske karakteristike kompozitnih mernih instrumenata (2. izdanje). Priština: Fakultet za fizičku kulturu.

Mulaik, S.A. (1972). The foundations of factor analysis, New York: McGrawHill.

Nunnally, J. C., Bernstein, I. H. (1994). Psychometric theory (3. izdanje). New York: McGraw-Hill Series in Psychology.

O'Connor, B. P. (2000). SPSS, SAS, and Matlab programs for determining the number of components using parallel analysis and Velicer's MAP test. Behavior Research Methods, Instruments, E Computers, 32, 396-402.

SPSS Inc. (2005). SPSS 14.0 Command syntax reference. Chicago-IL: Author.

Thompson, B. (2004). Exploratory and comfirmatory factor analysis: Understanding concepts and applications. Washington, DC: American Psychological Association. 


\title{
ABSTRACT
}

\section{KAKAOKTT: SET OF SPSS MACROS FOR ITEM ANALYSIS - CLASSICAL TEST THEORY}

\author{
Stanislav Fajgelj and Bojan Janičić
}

A set of newly developed computer programs called "Kakao" are presented in this paper. The set of programs is intended for the item analysis of instruments in the field of behavioral sciences. The programs are developed in Matrix program language as macros for statistical package SPSS for Windows. These macros are open source programs, which are free and very simple to use. They can run only within SPSS statistical package.

KakaoKTT is designed for the item analysis based on the Classical Test Theory and its supportive models. It contains a selection of measuring characteristics of items and their respective tests, along with a short description of each presented coefficient. Besides classical indicators of measuring characteristics, there are a number of indicators based on Guttman's measurement model. KakaoKTT accepts dichotomous and polychotomous items scored in the same direction.

Key words: item analysis, Classical test theory, Guttman measurement model 